I993 Papers of the

Fall Bibliographical Society

of Canada

I993 Cahiers de la

Automne Société bibliographique

du Canada

Volume 3 I, \#2

The Bibliographical Society of Canada La Société bibliographique du Canada Toronto, Canada I993

ISSN 0067-6896 



\section{Table of Contents / Table des matières}

Editorial Note / Préliminaire

The Publication of Thomas Chandler Haliburton's

The Clockmaker, 3rd Series

RUTH PANOFSKY

Notes on Samuel Hearne's Journey From a Bibliographical

Perspective

I.S. MACLAREN

Books in Review / Comptes rendus

CARL SPADONI and/et FRANÇOIS MELANÇON

D.J. McTernan, Le Québec français. Imprimés en français du Québec I764I990 à la British Library (Marie-Elaine Savard); Ruth Panofsky, Adele Wiseman: An Annotated Bibliography (Lorna Knight); John Richardson, The Canadian Brothers (Dennis Duffy); Evelyn J. Peters, Aboriginal Self-Government in Canada: A Bibliography, 1987-90; Jim Harding and Beryl Forgay, Breaking Down the Walls: A Bibliography on the Pursuit of Aboriginal Justice; Jim Harding and Bruce Spence, An Annotated Bibliography of AboriginalControlled Justice Programs in Canada (Linda Fritz); Neil Sutherland, Jean Barman, and Linda L. Hale, History of Canadian Childhood and Youth: A Bibliography (Adele Fasick); Lawrence J. McCrank, Bibliographical Foundations of French Historical Studies (Sally O'Driscoll); Stéphane Vachon, Les travaux et les jours d'Honoré de Balzac: Chronologie de la création balzacienne (Martine Léonard); Leila Luedeking and Michael Edmonds, Leonard Woolf: A Bibliography (Elizabeth P. Richardson); Wayne G. Hammond and Douglas A. Anderson, J.R.R. Tolkein: A Descriptive Bibliography (Gillian Fenwick); David Butcher, The Stanbrook Abbey Prees, 1956-1990 (Carl Spadoni)

Brief Notices / Notices abrégées 